\title{
Monumente zu Ehren Kaiser Josephs II. Ökonomisierung und Standardisierung im Denkmalkult
}

Abstract: Des Habsburgerkaisers Joseph II. (reg. I765-I790) wurde im späten I9. Jahrhundert in den österreichischen Erblanden, speziell in Niederösterreich, sowie in Böhmen mittels zahlreicher ganzfiguriger Monumente gedacht, wobei der Regent vor allem aufgrund seiner Religionspolitik und der von ihm initiierten Befreiung des Bauernstandes hohes Ansehen genoss. Die Statuen stammen zum Großteil aus der mährischen Gießerei in Blansko und zeigen keine ausgefeilten ikonografischen Programme, sondern sollten den Regenten in Form allgemein verständlicher und eingängiger Lösungen mit hohem Wiedererkennungswert populär halten. An dieser Produktion zeigt sich einerseits die mit der Gusstechnik unmittelbar verbundene Ökonomisierung des Denkmalkults, andererseits die für das späte I9. Jahrhundert charakteristische politisierende Besetzung ganzer Regionen, die fernab von den großen Metropolen - zu heiß umkämpften Schauplätzen der habsburgischen Erinnerungskultur wurden.

Monuments in Honour of Emperor Joseph II. Economization and Standardization in the Cult of Monuments. The Habsburg Emperor Joseph II (r. I765-1790) was commemorated in the late $19^{\text {th }}$ century in the Austrian hereditary lands, especially in Lower Austria, and in Bohemia, by means of numerous full-length monuments, whereby the ruler was held in high esteem above all because of his religious policy and the liberation of the peasantry he initiated. Most of the statues come from the Moravian foundry in Blansko and do not show elaborate iconographic programmes, but were intended to popularise the regent in the form of generally understandable, easily recognisable solutions. This production demonstrates on the one hand the economization of the cult of monuments directly linked to casting technology, and on the other hand the politicizing coding of entire regions characteristic of the late I $9^{\text {th }}$ century which - far from the major metropolises - became hotly contested sites of the Habsburg culture of remembrance.

Keywords: memory culture, Habsburg ruler representation, monuments, casting technique

doi.org/10.52035/noil.2021.19jh02.24

Veröffentlicht nach externer Begutachtung (doppelblind) / published after external peer review (double blind) 